\title{
EDITORIAL
}

\section{Adiós Amigo - Passing the baton}

\section{Chander Mohan, SM}

Director, Interventional Radiology, BLK Superpsecialty Hospital, Pusa Road, New Delhi, India. E-mail: brigcmohan@gmail.com

\section{Dear Colleagues,}

As you are aware that I will be completing my term as Editor-in-Chief here at IJRI in January 2019 and it is my last editorial as Editor-in-Chief of IJRI, I wanted to take a moment to let all of you know how much I have enjoyed my time here to the fullest. It has been a great experience working with you all. I have learned so much from your inputs, experience, advice, constructive criticism, and guidance during the last 3 years, and my time spent as Editor-in-Chief on this team has been such a valuable part of my career journey. I convey my deep appreciation to the core team consisting of Dr. Ashu Seith Bhalla, Joint Editor, Dr. Amar Mukund, Dr. Raj Singh Negi, Dr. George K. Chiramel, Dr. Kushaljit Singh Sodhi, Associate Editors, and Ms. Nisreen, Secretarial Assistant, IJRI, Mr. Harish Saryal and Mr Deepak, administrative staff at IRIA HQ for the all the hard work, co-operation, tremendous effort, and time devoted for IJRI during my tenure. I also take this opportunity to convey my sincere thanks to each and every member of the editorial board, our valued reviewers, past and present office bearers of IRIA, ICRI, IJRI, Central Council members, members of IRIA, Medknow team, and above all authors across the globe who helped me to learn new levels of professionalism. I also acknowledge Dr. Jiten Kumar, my former resident, for the ever-willing assistance and support for the journal work. I will always look back on this editorial tenure with a lot of fondness.

In my time in this position of repute, the present editorial team followed the policy of participative functioning and tried to make humble contribution to the journal to the best of our abilities. This included timely printing of all issues, elevating focus on original articles and review articles, and initiation of acknowledging the contribution of the reviewers in the form of awards to two best reviewers every year. Keeping in view the demand to create awareness among radiology residents and younger colleagues and help them to submit quality articles to $I J R I$, the first ever dedicated workshop was organized by IJRI in association with IRIA in July this year at IRIA House, New Delhi. This unique workshop received an overwhelming response and was attended by a large number of participants including those who attended its webcast. In addition, I thank the office bearers of IRIA and ICRI for a making a dedicated journal session mandatory during the Annual Conference of IRIA and including topics related to scientific paper writing during IREPs and CMEs organized by IRIA and ICRI, respectively. I am sure all state chapters of IRIA will also include at least one dedicated lecture on journal-related topics in all the scientific programs organized by them.

I have tried to focus on the subjects of importance in our specialty in the form of my editorials which were well-received. Perhaps the feather in the cap was indexing of the journal with Emerging Sources Citation Index (ESCI).

As much as I have enjoyed working here and relished the rewards of being a part of a team featuring such an esteemed group of peers, I have to pass the baton to the next illustrious editorial team that will be in place from the third week of coming January. I wish them all the best and hope that the journal will continue to attain greater heights under the new team.

May IJRI continue to disseminate the knowledge in the fascinating and ever-evolving field of Radiology with scholarly content and global perspective.

Long live IRIA !

Jai Hind !!

This is an open access journal, and articles are distributed under the terms of the Creative Commons Attribution-NonCommercial-ShareAlike 4.0 License, which allows others to remix, tweak, and build upon the work non-commercially, as long as appropriate credit is given and the new creations are licensed under the identical terms.

\begin{tabular}{|c|c|}
\hline \multicolumn{2}{|c|}{ Access this article online } \\
\hline Quick Response Code: & \multirow[b]{2}{*}{$\begin{array}{l}\text { Website: } \\
\text { www.ijri.org }\end{array}$} \\
\hline & \\
\hline & $\begin{array}{l}\text { DOI: } \\
\text { 10.4103/ijri.IJRI_455_18 }\end{array}$ \\
\hline
\end{tabular}

Cite this article as: Mohan C. Adiós Amigo - Passing the baton. Indian J Radiol Imaging 2018;28:379. 